\title{
Regulation and Accumulation of Copper, Zinc and Cadmium by the Shrimp Palaemon elegans
}

\author{
S. L. White and P. S. Rainbow \\ Department of Zoology and Comparative Physiology, Queen Mary College, Mile End Road, London E1 4NS, England
}

\begin{abstract}
The ability of Palaemon elegans Rathke, 1937 to regulate internal concentrations of copper, zinc and cadmium has been investigated over a wide range of external metal concentrations. Total body concentrations of copper and zinc are regulated on exposure to dissolved metal concentrations up to $100 \mathrm{\mu g} \mathrm{l}^{-1}$ metal. Exposure to higher levels of dissolved copper and zinc produces an increase in the metal concentration of the shrimps. Body concentrations of copper may increase by a factor of at least 5 times but only twice the normal body concentration of zinc could be tolerated by the shrimps. Cadmium concentrations are not regulated, the body concentration of metal being proportional to the external metal concentration.
\end{abstract}

\section{INTRODUCTION}

The phenomenon of accumulation of heavy metals by marine invertebrates has been extensively reported (see Bryan, 1979, and Prosi, 1979, for recent reviews) although the mechanisms by which this occurs are poorly understood.

Although toxic in excess, some heavy metals - notably copper and zinc - are essential trace elements required, for example, for the metabolic functioning of proteins such as haemocyanin $(\mathrm{Cu})$ or carbonic anhydrase $(\mathrm{Zn})$. It might be expected therefore that an ability to regulate the internal concentration of such metals may have been developed by marine invertebrates. It also seems likely that if these regulating processes occur there might be operational limitations beyond which regulation breaks down.

This study examines whether the intertidal shrimp Palaemon elegans Rathke, 1937 is able to regulate the 2 essential trace elements copper and zinc over a wide range of dissolved concentrations. The ability of $P$. elegans to regulate another metal, cadmium, is also examined. Cadmium is a toxic metal accumulated naturally by marine organisms but as yet has no known metabolic role.

\section{MATERLALS AND METHODS}

Palaemon elegans obtained from Millport, Isle of Cumbrae, Firth of Clyde, U.K. were acclimated in laboratory seawater at $10^{\circ} \mathrm{C}$ for at least $4 \mathrm{~d}$ after arrival. Experimental animals were then acclimated to the experimental medium, Tropic Marin New (T.M.N.) (Tropicarium Buchschlag, Dreieich, F. R. Germany) for a further $4 \mathrm{~d}$ before commencing experiments.

Groups of male and female shrimps in the size range 35-50 mm total length were initially selected for experiments such that each group contained shrimps of a similar size range in order to obviate any effects caused by size differences. Later work (S. L. White unpubl.) confirmed that there is no relation between size of shrimp and body concentrations of copper, zinc and cadmium, and so individual shrimps of varying size could safely be used for experiments without grouping

T.M.N was chosen as experimental medium because it provided a more reproducible medium than laboratory seawater, which had been stored for some time after collection, particularly with respect to dissolved organic matter which might chelate any added metal. Moreover, T.M.N. prepared with freshly distilled water was confirmed to contain lower original concentrations of copper, zinc and cadmium than laboratory seawater. The concentrations of these metals were measured by flame atomic absorption spectrophotometry (A.A.S.) on a Varian AA 375 Spectrophotometer using background correction after solvent extraction with ammonium pyrrolidine dithiocarbamate and 4-methylpentan-2-one (Hopkin and Williams, Chadwell Heath, Essex, U.K.) according to Cresser (1978). T.M.N. contained levels of 6.0, 2.5 and 
$0.5 \mu \mathrm{g}^{-1}$ for copper, zinc and cadmium respectively. To bring dissolved metal levels to the required experimental concentrations, additional metal was added from standard stock solutions prepared in each case from the Analar grade chloride salt (BDH Ltd., Poole, Dorset, U.K.) dissolved in distilled water. Any salinity changed was negligible because of the small volume of standard required in each case.

The experimental media were changed every $5 \mathrm{~d}$ and metal levels monitored periodically by A.A.S. after solvent extraction as previously described. The salinity was maintained at 33 ppt throughout experiments.

Experiments were carried out at $10^{\circ} \mathrm{C} \pm 1 \mathrm{C}^{\circ}$ under a 12:12 h light regime in acid washed tanks, and the medium was continuously aerated. Every other day the shrimps were removed from experimental and control tanks and allowed to feed for 15 min on lamb's heart in fresh T.M.N., thus avoiding any fouling of the experimental water. Lamb's heart was taken readily as food and had suitably low concentrations of copper, zinc and cadmium $\left(17,77\right.$ and $0.4 \mu \mathrm{g} \mathrm{g}^{-1} \mathrm{dry}$ weight respectively) to have any negligible effect as a dietary source of metal during the experimental period.

The 3 experiments were carried out over slightly different dates during the summer and while each lasted $21 \mathrm{~d}$ they differed slightly in detail.

(A) Copper experiment. Groups of 24 shrimps were exposed to nominal concentrations of 6 (control), 31.62, 100,316.2, 1,000, 3,162 and 10,000 $\mu \mathrm{g}$ $1^{-1}$ copper in 51 of T.M.N.

(B) Zinc experiment. Groups of 12 shrimps were exposed to nominal concentrations of 2.5 (control), 31.62, 100,316.2, 1,000,3,162 and $10,000 \mu \mathrm{g} \mathrm{l}^{-1}$ zinc in 41 of T.M.N.

(C) Ca d mi um experiments. (i) Groups of 12 shrimps were exposed to nominal concentrations of 0.5 (control), 10, 31.62, 100, 316.2 and 1,000 $\mathrm{g} \mathrm{l}^{-1}$ cadmium in $4 \mathrm{l}$ of T.M.N. For analysis individuals were paired to bring the cadmium concentration in the digests to $0.02 \mu \mathrm{g} \mathrm{ml}^{-1}$. (ii) In the light of this experiment a second experiment was set up in which groups of 12 shrimps were exposed to nominal concentrations of 0.5 (control), 2.5, 5.0 and $10.0 \mu \mathrm{g} \mathrm{l}^{-1}$ cadmium. For technical reasons it was necessary to carry out this second cadmium experiment at $15^{\circ} \mathrm{C} \pm 1 \mathrm{C}^{\circ}$.

During the experiments observations were made every day, and dead shrimps and moults removed. After $21 \mathrm{~d}$ surviving individuals were rinsed briefly in clean T.M.N. and weighed wet (for later calculations of wet: dry weight ratios). The shrimps were then dried to constant weight at $60^{\circ} \mathrm{C}$ and digested in concentrated nitric acid (Ultar grade, Hopkin and Williams, Chadwell Heath, Essex, U.K.) at $100{ }^{\circ} \mathrm{C}$. Samples were analysed by A.A.S. using standards in the same acid matrix.
Metal concentrations of shrimps in different metal exposures have been compared statistically with concentrations in control shrimps using Student's t-tests, after confirmation that data were distributed normally and parametric tests were therefore applicable. In the case of copper and zinc data, an a posteriori sum of squares simultaneous test procedure was also carried out (Sokal and Rohlf, 1969). All regression lines were fitted by least squares.

\section{RESULTS}

\section{Metal Concentration in Experimental Media}

Regular monitoring of the metal concentration in the experimental media showed that the concentrations were within $10 \%$ of the declared values, generally being slightly lower than the value quoted. This was true of all treatments except for the $10,000 \mu \mathrm{g} 1^{-1}$ copper concentration where some copper precipitated out to give a saturated solution of approximately $7,500 \mu \mathrm{g}$ $1^{-1}$. This value will be used throughout the study.

\section{Exposure to Elevated Levels of Copper, Zinc and Cadmium}

Table 1 gives a record of survivorship of shrimps exposed to the increasing levels of copper, zinc and cadmium after $21 \mathrm{~d}$. As stated above the dissolved metal concentrations were always within $10 \%$ of the original value and there was no correlation between changes in shrimp biomass as a result of mortality and changes in available metal concentrations.

Figs. 1, 2 and 3,4 show the concentrations of copper, zinc and cadmium respectively in surviving shrimps after $21 \mathrm{~d}$ exposure.

\section{Copper}

Fig. 1 shows that the whole body copper concentration remains roughly constant after $21 \mathrm{~d}$ exposure to a wide range of lower copper concentrations. There is no significant difference $(\mathrm{p}<0.05)$ in the mean body copper concentration between control shrimps and shrimps exposed to concentrations up to $100 \mu \mathrm{g} \mathrm{l}^{-1}$. Similarly, a sum of squares simultaneous test procedure confirmed that there were no significant differences in mean shrimp copper concentrations up to the $100 \mu \mathrm{g} \mathrm{Cu} 1^{-1}$ exposure and that these were significantly lower than those for higher exposures. Exposure to higher concentrations causes the metal concentration in the shrimps to rise rapidly in direct proportion 
Table 1. Palaemon elegans. Survivorship data for copper, zinc and cadmium experiments showing number of shrimps surviving after $21 \mathrm{~d}$. - no experiment at this exposure level

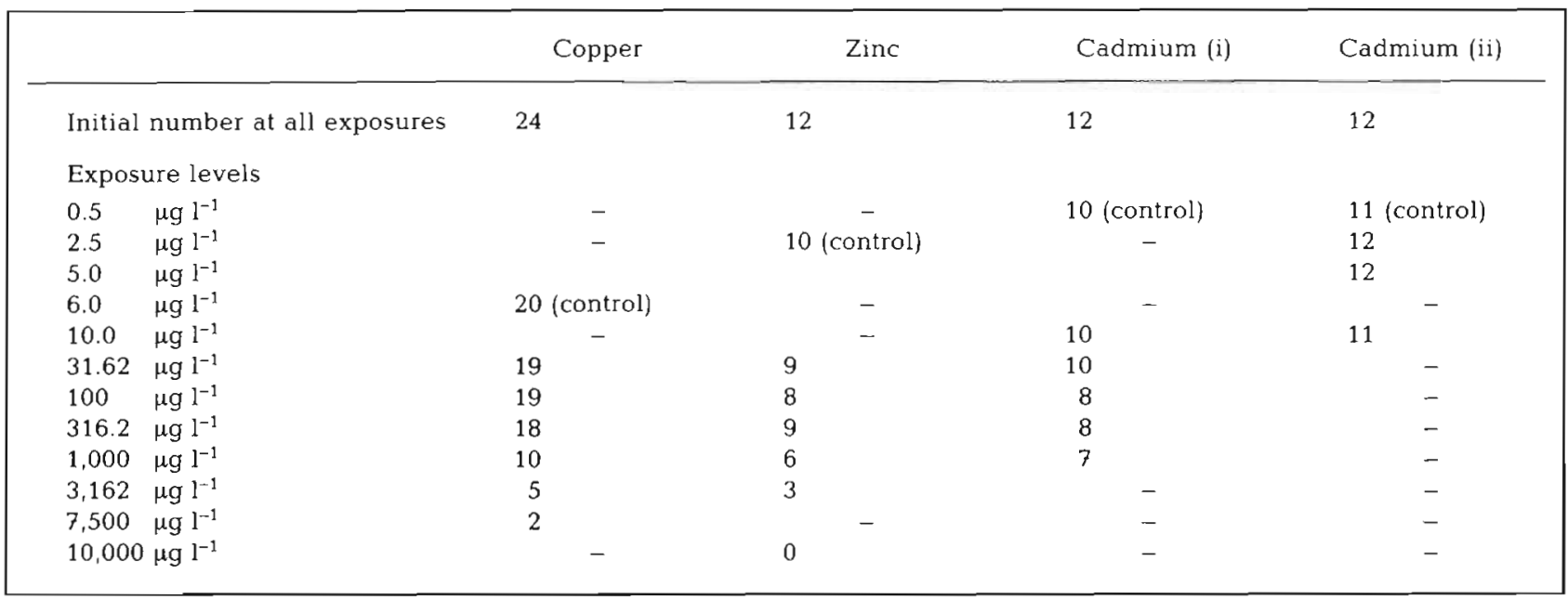

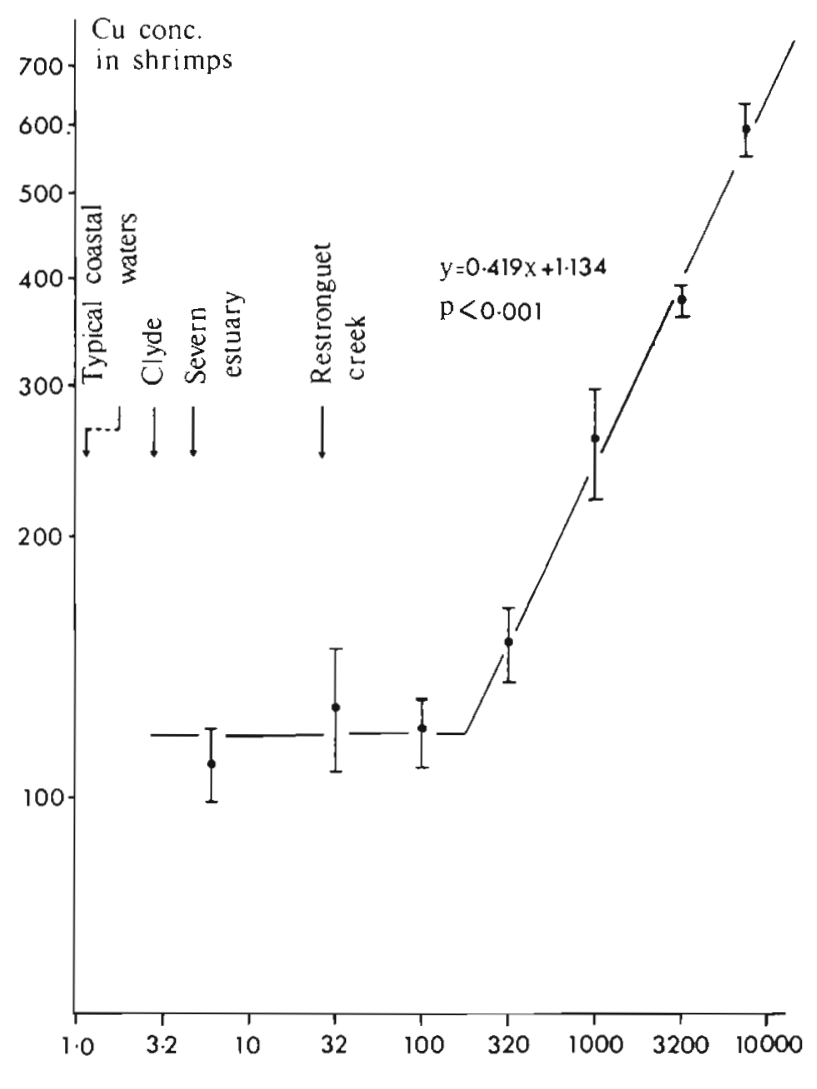

Exposed $\mathrm{Cu}$ conc

Fig. 1. Palaemon elegans. Mean body concentration of copper ( $\mu \mathrm{g} \mathrm{g}^{-1}$ dry weight \pm 1 standard deviation) in shrimps exposed to increasing concentrations of dissolved copper ( $\mu \mathrm{g}$ $\left.1^{-1}\right)$ for $21 \mathrm{~d}$ at $10^{\circ} \mathrm{C}(\log -\log$ plot). Arrows: reported concentrations of copper (see text) in typical coastal waters $(<1 \mu \mathrm{g}$ $1^{-1}$; Preston, 1973), Clyde Estuary (2.8 $\mathrm{gg} \mathrm{l}^{-1}$; Preston, 1973), Severn Estuary (4.6 $\mu \mathrm{g} \mathrm{l}^{-1}$; Preston, 1973) and Restronguet Creek (26 $\mu \mathrm{g} \mathrm{l}^{-1}$; Boyden et al., 1979). Regression equation applies only to final 4 points to the external copper concentration. Thus it appears that the total copper concentration is regulated at approximately $110 \mu \mathrm{g} \mathrm{g}^{-1} \mathrm{dry}$ weight, at least when exposed to dissolved copper concentrations of up to $100 \mu \mathrm{g} \mathrm{l}^{-1}$

\section{Zinc}

Fig. 2 illustrates the effect of exposure for $21 \mathrm{~d}$ to increasing dissolved zinc levels on the exposed shrimps. Again there is no significant difference between the mean metal body concentration of control

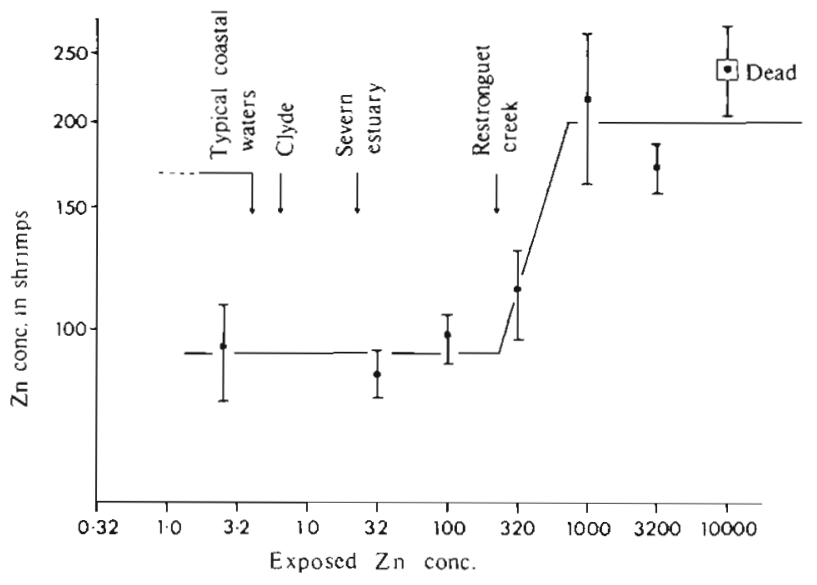

Fig. 2. Palaemon elegans. Mean body concentrations of zinc ( $\mu \mathrm{g} \mathrm{g}^{-1}$ dry weight \pm 1 standard deviation) in shrimps exposed to increasing concentrations of dissolved zinc $(\mu \mathrm{g}$ $\left.1^{-1}\right)$ for $21 \mathrm{~d}$ at $10^{\circ} \mathrm{C}(\log -\log$ plot). Arrows: reported levels of zinc (see text) in typical coastal waters $\left(<4 \mu \mathrm{g} \mathrm{l}^{-1}\right.$; Preston, 1973). Clyde Estuary (6.2 $\mathrm{g} \mathrm{I} \mathrm{I}^{-1}$; Preston, 1973), Severn Estuary $\left(22.2 \mu \mathrm{g} \mathrm{l}^{-1}\right.$; Preston, 1973) and Restronguet Creek $(217 \mu \mathrm{g}$ $\mathrm{l}^{-1}$; Boyden et al., 1979) 


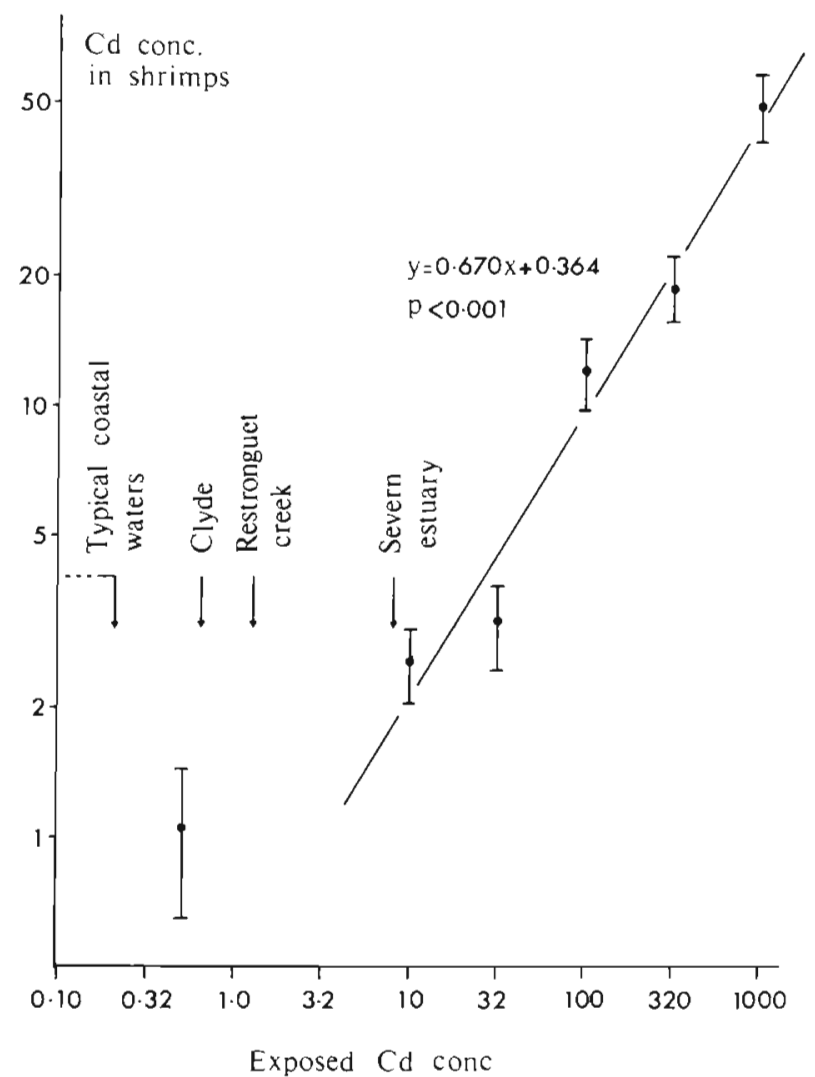

Fig. 3. Palaemon elegans. Mean body concentrations of cadmium ( $\mu \mathrm{g} \mathrm{g}^{-1}$ dry weight \pm 1 standard deviation) in shrimps exposed to increasing concentrations of dissolved cadmium ( $\left.\mu \mathrm{g}^{-1}\right)$ for $21 \mathrm{~d}$ at $10^{\circ} \mathrm{C}$ ( $\log -\log$ plot). Arrows: reported concentrations of cadmium (see text) in typical coastal waters $\left(<0.2 \mu \mathrm{g} \mathrm{l}^{-1}\right.$; Preston, 1973), Clyde Estuary $\left(0.6 \mu \mathrm{g} \mathrm{I}^{-1}\right.$; Preston, 1973), Severn Estuary (7.7 $\mu \mathrm{g} \mathrm{l}^{-1}$; Preston, 1973) and Restronguet Creek $\left(1.2 \mu \mathrm{g} \mathrm{l}^{-1}\right.$; Boyden et al., 1979). Regression equation excludes first point

shrimps and shrimps exposed to zinc levels up to $100 \mu \mathrm{g} \mathrm{l}^{-1}$. The a posteriori sum of squares simultaneous test procedure also revealed no significant difference in mean shrimp zinc concentrations up to $100 \mu \mathrm{g}$ $\mathrm{Zn} \mathrm{l^{-1 }}$; these were significantly lower than those for higher exposures. This implies an ability of the shrimps to regulate total zinc up to this level of exposure. At higher levels of dissolved zinc there is a sharp increase in body zinc concentration, but in contrast to copper the body zinc concentration appears to reach a plateau at around $200 \mu \mathrm{g} \mathrm{g}^{-1}$ zinc. The data given for $10,000 \mu \mathrm{g} \mathrm{I}^{-1}$ zinc are for dead shrimps, none survived the $21 \mathrm{~d}$ period. Even in this case the highest measured individual body concentration was only $300 \mu \mathrm{g} \mathrm{Zn} \mathrm{g}^{-1}$ dry weight.

\section{Cadmium}

Fig. 3 shows that when shrimps are exposed to cadmium levels between 10 to $1,000 \mu \mathrm{g}^{-1}$ cadmium, the

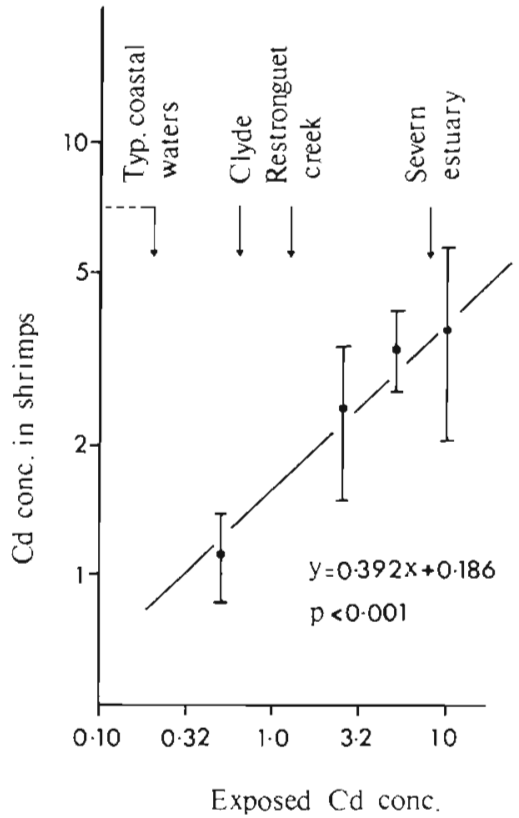

Fig. 4. Palaemon elegans. Mean body concentrations of cadmium ( $\mu \mathrm{g} \mathrm{g}^{-1}$ dry weight \pm 1 standard deviation) in shrimps exposed to increasing concentrations of dissolved cadmium ( $\mu \mathrm{g}^{-1}$ ) for $21 \mathrm{~d}$ at $15^{\circ} \mathrm{C}$ (log-log plot). Arrows: reported concentrations of cadmium as detailed in Fig. 3

cadmium concentration in the shrimps is directly proportional to the external concentration. The data for the controls $\left(0.5 \mu \mathrm{g} \mathrm{l}^{-1}\right)$ does not fall very close to the line of best fit possibly indicating some regulation of internal cadmium levels at low cadmium concentrations. A second experiment was therefore set up to investigate this possibility (Fig. 4). From Fig. 4 it is apparent that accumulation and not regulation occurs even at low cadmium exposures.

\section{DISCUSSION}

The ability of some marine crustaceans, generally decapods, to regulate internal concentrations of heavy metals, particularly copper and zinc has occasionally been reported in the literature (Bryan, 1971; Martin, 1974; Wright, 1976). However, there have been few experimental studies demonstrating regulation and these have generally used only a narrow range of metal concentrations. The experiments reported here use a wide range of copper, zinc and cadmium concentrations in an attempt to demonstrate not only that regulation occurs but also to find the limitations of the homeostatic mechanisms.

The results presented show that Palaemon elegans is able to regulate total body levels of copper and zinc up to a threshold exposure level beyond which the metals 
are accumulated in direct proportion to external metal levels. There are presumably 2 components of total body copper and zinc, an internal metal load potentially under metabolic control (and therefore able to be regulated) and a passively adsorbed metal load, for example, onto the exoskeleton; this could not be under metabolic control and would be accumulated in proportion to external dissolved metal levels (up to a saturation level if there is a maximum number of binding sites available). In the case of both copper and zinc, the total body metal concentrations did not alter significantly with increased metal exposure below the threshold exposure, and so at these exposures any passively adsorbed metal could not have changed in such a way to affect total body metal levels. Therefore, either the passively adsorbed metal increases over the exposure range (but is such a low percentage of the total body metal at all these low exposures to be swamped by constant internal levels), or the passively adsorbed metal has already reached a maximum and is thus constant. In either case regulation of internal metal levels must be occurring. Once this regulation has broken down, the total body metal level rises in proportion to external metal levels, presumably including a rise in passively adsorbed metal unless this component has already been saturated.

Working on Carcinus maenas Bryan (1976) demonstrated that crabs exposed to $200 \mu \mathrm{g} \mathrm{l} \mathrm{l}^{-1}$ zinc showed only a 4 fold increase in the whole body concentration of zinc compared with crabs exposed to only $4 \mu \mathrm{g} \mathrm{l}^{-1}$. In most tissues the zinc content increased markedly only after exposure to dissolved zinc levels above $200 \mu \mathrm{g} \mathrm{l} \mathrm{l}^{-1}$.

Palaemon elegans appears to show a limit to the concentration of zinc tolerated in the body, this limit being only twice that of the regulated concentration of about $100 \mu \mathrm{g} \mathrm{Zn} \mathrm{g}^{-1} \mathrm{dry}$ weight. This whole body concentration is, however, held constant at least up to dissolved zinc levels of $100 \mu \mathrm{g} \mathrm{l}^{-1}$, only increasing significantly $(\mathrm{p}<0.05)$ at exposures above $320 \mu \mathrm{g}$ $\mathrm{Zn} \mathrm{l}^{-1}$. These results suggest similarities between the ability of the 2 species to regulate zinc. The increase in total body zinc concentration in Carcinus maenas at low dissolved zinc concentrations is largely due to passive adsorption onto the carapace (Bryan, 1976) and therefore not under metabolic control. The soft tissues of $C$. maenas, however, show little change at exposures up to $200 \mu \mathrm{g} \mathrm{l}^{-1}$, indicating a marked ability on the part of C. maenas to regulate internal zinc concentrations. Bryan (1964) showed that the lobster Homarus vulgaris could also regulate at least internal tissue zinc concentrations at exposures up to $100 \mu \mathrm{g} \mathrm{l}^{-1} \mathrm{zinc}$ and after injection with zinc.

There is no comparative experimental data for copper regulation in decapod crustaceans, though Bryan
(1968) suggests they may have some homeostatic ability, this suggestion being based on the similarity of copper concentrations in a large number of species.

Levels of $100 \mathrm{Mg}^{-1}$ copper and zinc are considerably greater than levels of 4 and $10 \mu \mathrm{g} \mathrm{l}^{-1}$, respectively, found in clean near-shore waters by Preston (1973), although metal concentrations at the shoreline itself would probably be higher as a result of runoff from the land and leaching from substrates. Since Palaemon elegans is found in the intertidal zone, metal concentrations taken at the shoreline are the most relevant for comparison with those used in this study. Included in Figs. 1 to 4 are some of the few available concentrations taken at the shoreline for sites around the U.K. In the case of these shoreline sites, levels quoted from Preston (1973) are integrated values based on seaweed concentrations, whereas levels from Boyden et al. (1979) are maximum values of several mean concentrations of metals measured from Restronguet Creek. Shoreline figures of copper and zinc appear to fall within the range where $P$. elegans can regulate body concentrations of the 2 metals, although in sites of very high levels such as Restronguet Creek (Boyden et al., 1979) zinc concentrations may exceed the range of regulation.

Since Palaemon elegans has the ability to regulate copper and zinc we would expect to find similar concentrations of these 2 metals in shrimps collected from different field sites, except in shrimps collected from sites with extremely high ambient metal concentrations. Table 2 lists concentrations of zinc, copper and cadmium for $P$. elegans and other shrimps/prawns from a number of locations. It is clear that the concentrations for copper and zinc are all very similar and in agreement with the experimental evidence presented here for copper and zinc regulation.

Unlike copper and zinc, cadmium is apparently not regulated by Palaemon elegans at the concentrations used in this study. The concentration of cadmium in the shrimp is directly proportional to the concentration in the surrounding seawater. Other workers have also shown experimentally that cadmium is not regulated by decapods (Vernberg et al., 1974; Bengtsson, 1977; Wright, 1977; Dethlefsen, 1978; Jennings and Rainbow, 1979). Given this experimental evidence we might expect the cadmium concentration in P. elegans and other shrimps/prawns from different locations to reflect the cadmium concentration in the seawater. The data in Table 1 generally show low concentrations of cadmium close to that typical for decapod crustaceans given by Bryan (1976) of $1 \mu \mathrm{g} \mathrm{g}^{-1}$ dry weight. This probably reflects the generally low level of cadmium in nearshore U.K. waters $\left(0.5 \mu \mathrm{g} \mathrm{l}^{-1}\right.$; Preston et al., 1972). However, shrimps from the Bristol Channel (Peden et al., 1973) and Northumberland coast (Wright, 
Table 2. Comparison of whole body concentrations of zinc, copper and cadmium ( $\mu \mathrm{g} \mathrm{g}^{-1} \mathrm{dry}$ wt.) of shrimps/prawns in the present study and in others from U.K. waters. ${ }^{+}$calculated from original wet wt. concentrations using solid contents in Bryan (1968); ++ based on solid content of $28 \%$

\begin{tabular}{|c|c|c|c|c|}
\hline Species & Zine & Copper & Cadmium & References \\
\hline \multicolumn{5}{|l|}{ Palaemon elegans } \\
\hline Clyde Estuary & 93.4 & 109.2 & 1.05 & This study \\
\hline Rottingdean, Sussex & 87.2 & 129.2 & 1.87 & This study \\
\hline Plymouth, Devon & 104.5 & 108.0 & - & Bryan (1968) \\
\hline Solent, Hants & - & - & 0.31 & Leatherland \& Burton (1974) \\
\hline \multicolumn{5}{|l|}{ Palaemon serratus } \\
\hline Plymouth, Devon & 77.8 & 110.0 & - & Bryan (1968) \\
\hline Northumberland Coast & - & - & $10.4^{+}$ & Wright (1976) \\
\hline \multicolumn{5}{|l|}{ Palaemonetes varians } \\
\hline Plymouth, Devon & 80.3 & 128.5 & - & Bryan (1968) \\
\hline \multicolumn{5}{|l|}{ Pandalus montagui } \\
\hline Clyde Estuary & - & - & 1.9 & Halcrow et al. (1973) \\
\hline \multicolumn{5}{|l|}{ Crangon vulgaris } \\
\hline Plymouth, Devon & 118.9 & 111.9 & - & Bryan (1968) \\
\hline Northumberland Coast & - & - & $12.2^{+}$ & Wright $(1976)$ \\
\hline Medway, Kent & 92.3 & $64.7^{+}$ & $2.1^{+}$ & Wharfe \& Van der Broek (1977) \\
\hline \multicolumn{5}{|l|}{ Crangon allmani } \\
\hline Clyde Estuary & - & - & 2.2 & Halcrow et al. (1973) \\
\hline \multicolumn{5}{|l|}{ 'Shrimps' } \\
\hline Bristol Channel & - & - & $14.3^{++}$ & Peden et al. (1973) \\
\hline
\end{tabular}

1976) have markedly higher concentrations, both greater than $10 \mu \mathrm{g} \mathrm{g}^{-1}$ dry weight. As would be expected from the results of this study, both areas have been shown to be 'hot spots' for cadmium, with seawater concentrations up to 9.4 and $6.2 \mu \mathrm{g} \mathrm{l}^{-1}$ respectively being reported (Dutton et al., 1973; Abdullah and Royle, 1974)

The results obtained from highly elevated zinc and copper levels are of little more than academic interest since they are not likely to be met in the field. However, they do show a marked difference between the comparative physiology of the 2 metals in Palaemon elegans. The mean copper concentration in the shrimps surviving in the $7,500 \mu \mathrm{g} \mathrm{l}^{-1}$ exposure was 5 times that of the controls implying that $P$. elegans can either tolerate generally high tissue copper levels or is capable of effectively removing it from general circulation possibly by laying it down in particular tissues, perhaps for example in granular forms as has been found in the hepatopancreas of Crangon vulgaris (Djangmah, 1970). Zinc levels in shrimps exposed to higher zinc concentrations were found to each a maximum of approximately only double that in the control shrimps and it appears that elevated levels of tissue zinc cannot be tolerated. It seems therefore that there are differences in the toxic action of the 2 metals.

Cadmium concentrations of shrimps at the highest exposure level reached approximately 80 times that of the controls, and it appears that cadmium - although considered a non-essential toxic metal - can be tolerated in concentrations greatly beyond 'normal' tissue levels. However, the concentrations achieved during the $21 \mathrm{~d}$ exposure were still comparatively low, reaching $40 \mu \mathrm{g} \mathrm{g}^{-1}$ compared with the regulated level of about $100 \mu \mathrm{g} \mathrm{g}^{-1}$ of the chemically similar zinc. As cadmium is known to be an analogue for zinc in many metalloproteins (Wittmann, 1979) it may be that cadmium only becomes toxic when competing strongly with zinc for protein binding sites.

The ability of decapod crustaceans to regulate copper and zinc but not cadmium supports the hypothesis of Bryan (1979) that essential trace metals can be regulated, at least to some degree, while whole nonessential metals can not. Bryan and Ward (1965) have shown that the lobster Homarus vilgaris can regulate manganese, an essential metal, while Ray and Tripp (1976) demonstrated that the shrimp Palaemonetes vulgaris accumulates mercury, a non-essential metal, as does the crab Uca pugilator (Vernberg et al., 1974).

The ability of some decapods to regulate at least some metals is in contrast to the accumulation of these metals by lower Crustacea such as barnacles (Walker et al., 1975; Rainbow et al., 1980) and euphausids (Benayoun et al., 1974). These Crustacea are considered to be more primitive than decapods and may consequently have fewer physiological specialisations to deal with varying metal concentrations. Being relatively large, decapod crustaceans typically have cal- 
cified impermeable exoskeletons with specialised, permeable gill regions, in contrast to the extensive permeable body surfaces of lower crustaceans. Such localisation of permeability may be a preadaptation to the control of the entry/exit of a particular metal and therefore of its regulation. The lifestyle of the lower crustaceans may also be an important feature of their inability to regulate heavy metals; for the most part they are microphagous filter feeders, feeding on typically metal-rich plankton. Any filtering process inevitably involves the passage of large volumes of water across parts of the surface of the animal which, as stated, is usually permeable to dissolved ions in the seawater. This argument would also apply to planktonfeeding bivalves which are also extreme accumulators of metals, although ingestion of mucous sheets associated with feeding and a likely absorptive surface for metals may also be important in this case (Bryan, 1979).

Acknowledgement. S.L.W. was in receipt of an S.R.C. Studentship during this work

\section{LITERATURE CITED}

Abdullah, M. I., Royle, L. G. (1974). A study of the dissolved and particulate trace elements in the Bristol Channel. J. mar. biol. Ass. U.K. 54: 581-597

Benayoun, G., Fowler, S. W., Oregioni, B. (1974). Flux of cadmium through euphausids. Mar. Biol. 27: 205-212

Bengtsson, B. E. (1977). Accumulation of cadmium in some aquatic animals from the Baltic Sea. In: Aherblom, A. (ed.) 3rd Soviet-Swedish-Symposium on the pollution of the Baltic, Rosemon, Sweden 1975. Royal Swedish Academy of Sciences, Ambio Special Reports No. 5

Boyden, C. R., Aston, S. R., Thornton, I. (1979). Tidal and seasonal variations of trace elements in two cornish estuaries. Estuar. coast. mar. Sci. 9: 303-317

Bryan, G. W. (1964). Zinc regulation in the lobster Homarus americanus. I. Tissue zinc and copper concentrations. J. mar. biol. Ass. U.K. 44: 549-563

Bryan, G. W. (1968). Concentrations of zinc and copper in the tissues of decapod crustaceans. J. mar. biol. Ass. U.K. 48 303-321

Bryan, G. W. (1971). The effects of heavy metals (other than mercury) on marine and estuarine organisms. Proc. R. Soc. B 177: $389-410$

Bryan, G. W. (1976). Heavy metal contamination in the sea. In: Johnston, R. (ed.) Marine pollution. Academic Press, London, pp. 185-302

Bryan, G. W. (1979). Bioaccumulation of marine pollutants. Phil. Trans. R. Soc. B 286: 483-505

Bryan, G. W., Ward, E. (1965). The absorption and loss of radioactive and non-radioactive manganese by the lobster Homarus vulgaris. J. mar. biol. Ass. U.K. 45: 65-95

Cresser, M. S. (1978). Solvent extraction in flame spectroscopic analysis, Butterworths, London

Dethlefsen, V. (1978). Uptake, retention and loss of cadmium by brown shrimp (Crangon crangon). Meeresforschung 26: $137-152$
Djangmah, J. S. (1970). The effects of feeding and starvation on copper in the blood and hepatopancreas, and on blood proteins of Crangon vulgaris (Fabricius). Comp. Biochem. Physiol. 32: 709-731

Dutton, J. W. R., Jefferies, D. F., Folkard, A. R., Jones, P. G. W (1973). Trace metals in the North Sea. Mar. Pollut. Bull. 4 $135-138$

Halcrow, W., Mackay, D. W. Thornton, I. (1973). The distribution of trace metals and fauna in the Firth of Clyde in relation to the disposal of sewage sludge. J. mar, biol. Ass. U.K. 53: 721-739

Jennings, J. R., Rainbow, P. S. (1979). Studies on the uptake of cadmium by the crab Carcinus maenas in the laboratory. I Accumulation from seawater and a food source. Mar. Biol 50: $131-139$

Leatherland, T. M., Burton, J. D. (1974). The occurrence of some trace metals in coastal organisms with particular reference to the Solent region. J. mar. biol. Ass. U.K. 54: $457-468$

Martin, J.-L. M. (1974). Metals in Cancer irroratus (Crustacea: Decapoda). Concentrations, concentration factors, discrimination factors, correlations. Mar. Biol. 28: 245-251

Peden, J. D., Crothers, J. H., Waterfali, C. E., Beasley, J. (1973). Heavy metals in Somerset marine organisms. Mar. Pollut. Bull. 4: 7-10

Preston, A. (1973). Heavy metals in British waters. Nature, Lond. 242: 95-97

Preston, A., Jefferies, D. F., Dutton, J. W., Harvey, B. R., Steele, A. K. (1972). British Isles Coastal waters: the concentrations of selected heavy metals in seawater, suspended matter and biological indicators: a pilot survey. Environ. Pollut. 3: 69-82

Prosi, F. (1979). Heavy metals in aquatic organisms. In: Förstner, U., Wittman, G. W. T. (eds.) Metal pollution in the aquatic environment. Springer, Berlin, pp. 271-323

Rainbow, P. S., Scott, A. G., Wiggins, E. A., Jackson, R. W. (1980). Effect of chelating agents on the accumulation of cadmium by the barnacle Semibalanus balanoides, and complexation of soluble $\mathrm{Cd}, \mathrm{Zn}$, and Cu. Mar. Ecol. Prog. Ser. 2: 143-152

Ray, G. L., Tripp, M. R. (1976). The uptake of mercury from water by the grass shrimp Palaemonetes vulgaris (Say). J. Environ. Qual. 5: 193-197

Sokal, R. R., Rohlf, F. J. (1969). Biometry, Freeman and Co., San Francisco

Vernberg, W. B., DeCoursey, P. J., O'Hara, J. (1974). Multiple environmental factor effects on physiology and behaviour of the fidler crab Uca pugilator. In: Vernberg, F. J., Vernberg, W. B. (eds.) Pollution and physiology of marine organisms. Academic Press, New York, pp. 381-425

Walker, G., Rainbow, P. S., Foster, P., Crisp, D. J. (1975). Barnacles: possible indicators of zinc pollution? Mar. Biol. 30: $57-65$

Wharfe, J. R., Van der Broek, W. L. F. (1977). Heavy metals in macroinvertebrates from the lower Medway Estuary, Kent. Mar. Pollut. Bull. 8: 31-34

Wittmann, G. T. W. (1979). Toxic metals. In: Förstner, U. Wittmann, G. T. W. (eds.) Metal pollution in the aquatic environment. Springer, Berlin, pp. 3-68

Wright, D. A. (1976). Heavy metals in animals from the North East Coast. Mar. Pollut. Bull. 7: 36-38

Wright, D. A. (1977). The effect of salinity on cadmium uptake by the tissues of the shore crab Carcinus maenas $(L) . J$. exp. Biol. 67: 137-146 